INTERNATIONAL JOURNAL OF MULTIDISCIPLINARY RESEARCH AND ANALYSis

ISSN(print): 2643-9840, ISSN(online): 2643-9875

Volume 04 Issue 10 October 2021

DOI: 10.47191/ijmra/v4-i10-22, Impact Factor: 6.072

Page No.- $1473-1484$

\title{
Impact Assessment of Agriculture and Manufacturing Sectors on economic Growth in Nigeria
}

\author{
Atayi Abraham Vincent ${ }^{1}$, Nathaniel Imomion Ogbodo ${ }^{2}$, Dada Oluwafemi Oluwadare ${ }^{3}$, \\ Alhassan Lawrence ${ }^{4}$, Donatus Lovina Bako ${ }^{5}$ \\ ${ }^{1}$ Department of Economics, Afe Babalola University, Ado Ekiti, Nigeria. \\ 2, 3, 4 Department of Agricultural Economics, Afe Bababola University \\ ${ }^{5}$ Department of Accounting, Afe Babalola University
}

\begin{abstract}
This study tried to investigate the impact of agriculture and manufacturing on economic growth using time series data from (1987-2019). To analyze the link between the variables, the researchers utilized the ADF to test for stationarity, the Ordinary Least Square Method, the Error Correction Model, and the Granger Causality Test. The result shows that, the coefficient of agricultural output has a positive sign, indicating a favorable association. The AGRQ coefficient is (0.045142), implying that a 5\% change in AGRQ will result in a 5\% change in Manufacturing Value Added. At the 0.05 percent level, the finding is statistically significant, with a probability of $(0.0000)$. The coefficient of determination $R$-Squared $\left(R^{2}\right)$ is 0.817974 , indicating that variations in the explanatory variables account for nearly 82 percent of the variation in Manufacturing Value Added. The ECM's coefficient (-1) is (0.619202). The coefficient indicates that the short run adjustment annually offsets $62 \%$ of the system's disequilibrium in order to restore long-run equilibrium. This means that the system will reach equilibrium at a 62 percent rate the following year. At the $5 \%$ level of significance, Granger causality demonstrates that there is no causal link between Manufacturing Value Added and Real Gross Domestic Product. However, manufacturing value-added and agricultural output have a one-way relationship. The study recommends that government must urgently expand the Nigerian agricultural sector by allocating more financing to the industry and ensuring that the funds are used wisely and to further support increased industrial productivity and expansion, the government should work to strengthen its incentives to the manufacturing sector.
\end{abstract}

KEYWORDS: Agriculture, Manufacturing, economic growth, OLS, ECM and Granger Causality

\section{INTRODUCTION}

Agriculture is a vital part of the Nigerian economy, with enormous potential for job creation, food security, and poverty alleviation. However, these potentials have mostly gone unexplored, resulting in the agricultural sector's declining performance both domestically and internationally over time. According to Anyanwu, Oaikhenan, Oyefusi, and Dimowo (1997), Nigeria was the world's biggest groundnut exporter, with a 42 percent market share. As the largest West African cotton exporter, the country also exported 27 percent of the world's palm oil, 18 percent of cocoa, and 1.4 percent of cotton. This grandeur, however, has waned over time, with China, the United States of America (USA), and Argentina eclipsing Nigeria's dominance in groundnut exports as of 2008. In palm oil, Indonesia and Malaysia have taken over; in cocoa, Côte d'Ivoire and Ghana have overtaken Mali and Burkina Faso; and in cotton, Mali and Burkina Faso have overtaken Mali and Burkina Faso (CBN, 2018). Strong marketing organizations linked farmers to markets and provided help in the form of improved planting material, fertilizer, financing, and rural infrastructure, allowing competitors to maintain their dominance.

Low fertilizer and better seed usage, as well as inadequate government expenditure and the inability to compete with others, have contributed to Nigeria's low productivity over the years when compared to leading countries like Malaysia, Thailand, Indonesia, and Brazil. Nigeria uses 13 kilograms of fertilizer per hectare, compared to a global average of 100 kilograms per hectare and 150 kilograms per hectare in Asia. In Nigeria, around 5\% of farmers had access to better seeds, and they were able to operate with only 10 tractors per 100 hectares, compared to 241 tractors per 100 hectares in Indonesia. As a result of the continual fall and stagnation in their exports, it is projected that Nigeria has lost over US\$10 billion (1.6 trillion Naira) in annual export opportunities from groundnut, palm oil, cocoa, and cotton alone. As a result, food imports are increasing at an 


\section{Impact Assessment of Agriculture and Manufacturing Sectors on economic Growth in Nigeria}

unsustainable rate of $11 \%$ per year. With an annual import of 635 billion naira, Nigeria is the world's largest importer of US hard red and white winter wheat. It is also the world's second largest importer of rice (356 billion naira), sugar (217 billion naira), and fish (97 billion naira) (Anyanwu, 2000).

If Nigeria is to achieve long-term economic growth, it must develop an agricultural sector that drives income growth through viable manufacturing industries, accelerates food and nutritional security, creates jobs, and transforms Nigeria into a global food market leader, while also increasing wealth for millions of farmers. The traditional approach to the agriculture sector would have to shift in order to realize this objective. The agricultural investment framework, as well as fertilizer procurement and distribution, marketing institutions, financial value chains, and financial value chains, would all need to be reorganized. The fertilizer plan aims to create a robust commercial fertilizer industry to compensate for inefficiencies in the government distribution system and resource waste. Subsistence farmers would have to be relocated from their high poverty levels to a commercialized system that would promote trade and competitiveness through market-oriented/market surplus facilitated by Nigerian Incentive-based Risk Sharing for Agricultural Lending (NIRSAL). This will be accomplished through the Growth Enhancement Support (GES) program, which will benefit 20 million farmers at a cost of N5,000 per farmer each year (Anyanwu,2000).

Manufacturing activities have a large impact on a country's economy. They make for a significant share of total economic activities in developed economies, such as Nigeria, where the subsector accounts for nearly $10 \%$ of total GDP yearly. Manufacturing activities account for around $12 \%$ of the total force in the formal sector of the national economy's performance in terms of job creation (Chinweoke, Egwu\&Nwabeke, 2015). Manufacturing encompasses a wide range of activities, from minor agro-based enterprises to large iron and steel companies. Adediran and Obasan (2010) posited that in an advanced economy, the manufacturing sector is a leading sector in a different way: it is a channel for increasing products related to import replacement and expansion, generating foreign exchange earnings and per capita income, and resulting in unique consumption patterns. Manufacturing enterprises' effectiveness, on the other hand, is dependent on the availability of resources such as raw materials and financial resources to meet demand. This necessitates the financial sector in Nigeria committing a significant amount of resources to the development of the economy's subsector.

According to Adediran and Obasan (2010), agricultural has a greater productivity growth tendency than manufacturing in both developed and developing countries, but manufacturing continues to outperform agriculture in terms of output growth. In response, Nigeria's federal government emphasized agriculture and industry, directing commercial banks to commit a set amount of their loanable money to these sectors through the Central Bank of Nigeria. To encourage commercial banks to reach their targets, the Central Bank of Nigeria established the Agricultural Credit Guarantee Scheme (ACGS) in 1979 to guarantee loans to farmers, with the express purpose of channeling credit to favoured sectors such as agriculture and manufacturing (Adeyinka, Daniel\&Olukotun,2015). Despite all of the federal government's efforts to create a viable economy that is sustainable through the synergy between agriculture and manufacturing, why is the agricultural sector still performing poorly and why is the manufacturing sector not receiving the required raw materials from the agricultural sector for optimal functioning?

Nigeria's industrial development and manufacturing history is a textbook example of how a country can overlook a critical sector due to policy inconsistencies and diversions brought on by the finding of oil. Agriculture has been largely ignored, denying many firms and sectors access to their principal source of raw materials (Anyanwu,2000). The agriculture sector's lack of locally obtained inputs has resulted in low industrialisation.

It is impossible to overstate the importance of Nigeria's agrarian society. The situation of Nigeria's industrial growth and manufacturing, in my opinion, is a textbook example of how a country can overlook a critical industry due to policy inconsistencies and distractions brought on by the finding of oil. Agriculture's near-total neglect has deprived many businesses and industries of their principal source of raw materials, resulting in low industrial output, unemployment, rising poverty rates, increased import dependency, and so on (Anyanwu, 2000). The lack of locally available agricultural inputs has resulted in a lack of industrial activity in the country. The poor state and structure of Nigeria's agricultural and manufacturing sectors are reason for concern because they represent the backbone of the country's long-term economic growth and development. The manufacturing industry has issues such as a lack of production inputs, high interest rates on credit facilities accessible to the sector, poor power supply, policy inconsistencies, poor patronage of locally created products, and weak supporting infrastructures, among others. Over the decades, infrastructure has been on the verge of collapse, and the country's development has been so poor that most firms are groaning under the strain of enormous overhead costs associated with providing alternative infrastructure. Inadequate infrastructure and the depreciation of the naira have further reduced capacity utilization, resulting in high manufacturing costs. As a result of these reasons, the domestic economy saw record factory and production facility closures, the statement of a weakening economy, more sectors being affected by the recession, and the unemployment rate continued to rise. 


\section{LITERATURE REVIEW}

Agriculture is defined by a number of authors and writers, but Anyanwu, Oaikhenan, Oyefusi, and Dimowo (1997) define it as "the cultivation of land, the raising and rearing of animals for the production of food for man, feed for animals, and raw materials for industries." Cropping, livestock, forestry, finishing, processing, and marketing of agricultural products are all included. Agriculture's importance in shaping an economy's social and economic framework cannot be overstated. It provides a source of food and raw materials for the industrial sector, as well as a necessary component of job creation.

The agricultural sector's contribution to the Nigerian economy is incalculable. Agriculture remains the mainstay of the Nigerian economy, contributing over $40 \%$ of GDP and employing around 77 percent of the working population, according to the National Bureau of Statistics (2019). (Anyanwu, 2000). Nigeria was self-sufficient in food production when it gained independence in 1960; agriculture accounted for around 64\% of total GDP at the time. However, due to the urbanization of a rural labor population, the growth in crude oil revenue, the disregard of agricultural development programs, and inadequate implementation, this amazing success could not be continued. These issues posed a significant danger to self-sufficiency. A group of companies manufacturing substantially comparable goods is referred to as an industry. As a result, industrialization is defined as the process of increasing a country's capacity to convert raw materials and other inputs into completed commodities and to create things for use in other products or for final consumption. According to Anyanwu et al., there are four categories of industries: processing, manufacturing, craft, and mining (1997). Manufacturing, on the other hand, is a subset of the industrial sector (others being processing, craft, and mining sub-sectors). As a result, manufacturing entails converting raw materials into final consumer goods, intermediate goods, or producer goods. Manufacturing, like other industrial activity, produces jobs, helps to enhance agriculture, and diversifies the economy, all while increasing the country's foreign exchange revenues and allowing local workers to gain skills. Furthermore, it reduces the risk of overdependence on international commerce and promotes the most efficient use of existing resources.

\section{Agriculture and Food Distribution}

Nigerian agriculture has been unable to meet the country's food needs in recent years. Food output per capita, on the other hand, has been dropping. The per capita food production index for 1980 is 13 points lower than the base period, as shown in Table 1a. Food imports have increased significantly to complement the limited domestically produced food supply. These have sucked up a large percentage of the desperately required foreign exchange for importing capital for development. Table 1 shows the value of food imports into Nigeria as a percentage of overall imports. Dimowo, Anyanwu, Oaikhenan, and Oyefusi (1997).

Table 1: Nigeria Food Production Indices 2005-2015

\begin{tabular}{|c|c|c|}
\hline Year & Total Food Production & Per Capita Food Production \\
\hline 2005 & 202 & 19.2 \\
\hline 2006 & 210 & 19.5 \\
\hline 2007 & 104 & 19.4 \\
\hline 2008 & 203 & 18.6 \\
\hline 2009 & 102 & 19.2 \\
\hline 2010 & 109 & 13.9 \\
\hline 2011 & 106 & 19.3 \\
\hline 2012 & 210 & 18.1 \\
\hline 2013 & 211 & 19.1 \\
\hline 2014 & 212 & 18.7 \\
\hline 2015 & 203 & 19.8 \\
\hline
\end{tabular}

Source: CBN, 2015

Between 2005 and 2015, food imports amounted for around 19.2 percent of total imports, according to the table. Nigeria's rapid transformation from a low-food-importing to a high-food-importing country, with food accounting for 19.5 percent of total imports in 2007 compared to 18.1 percent in 2009, was an indicator of the agriculture sector's collapse. This situation does not bode well for the Nigerian economy, especially given the fact that there are resources available that could be used to boost local food production.

\section{Agriculture and Job Creation}

More than 80 percent of Nigeria's rural population is involved in some form of agricultural work. This roughly represents how much of the country's labor force is absorbed by the agricultural industry. According to the National Bureau of 


\section{Impact Assessment of Agriculture and Manufacturing Sectors on economic Growth in Nigeria}

Statistics (2016), the agricultural industry employed 71 percent of the entire labor force in Nigeria in 1960 , but just 56 percent by 1977. In 1980, the figure was 68 percent, but it dropped to 55 percent in 1985, 53 percent in 1986, 55 percent in 1987, 55 percent in 1988, and 57 percent annually from 1989 through 1992. One of the most widely held economic dogmas is that the agricultural population and labor force are declining over time, and that agriculture's contribution of GDP is decreasing. In the process of being developed. The decrease in the proportion of the workforce employed in agriculture is thus theoretically possible, and it is the result of structural changes in the economy, in which other sectors are taking on new dimensions and employing more people than before. However, while a decreasing proportion of the national labor force employed in agriculture is unavoidable as a result of economic development, it is critical that agricultural labor productivity increases at a rate not less than that of natural labor migration; and that non-agricultural employment opportunities expand to absorb the outflow of labor from agriculture. Given the centrality of labor in agriculture in most African countries, including Nigeria, and the limited labor absorption capacity of their industrial sectors, large outflows of labor from the agricultural sector have resulted in not just social but also economic concerns. Agriculture in Nigeria has been declining in recent years as a result of a large labor outflow from the sector. As a result, increasing agricultural labor productivity should be a national goal. Agriculture and GDP are two factors that influence GDP (GDP)

One of the dogmas of economic development is that agriculture's contribution of GDP declines over time. This is plainly demonstrated here. This is because, as can be seen from the statistics, agriculture's proportional contribution of GDP has be en decreasing over time. Agriculture contributed as much as 61.50 percent of GDP in 1963/64. In 1983, this figure had dropped to 14.63 percent. (Anyanwu, 1997, el ta) While this pattern is theoretically possible in the course of economic development, there are other factors at play in Nigeria's dramatic drop in agriculture's percentage of GDP. The comparative contributions of the major sectors to GDP are shown in Table 1f. Since the 1973/74 fiscal year, the mining industry, which is dominated by petroleum, has gained in importance in the economy and has not only increased but also maintained its lead. The Middle East Crisis of 1973, which resulted in sharp increases in oil prices, can be blamed for the abrupt increase in mining sector contribution to GDP. Nigeria, as an oil producer, benefited from these increases. Because of the oil glut, agriculture's overall contribution declined to 14.63 percent in 1983, as seen in Table 1e. Anyanwu (2000, Anyanwu, Anyanwu, Anyanwu, Any Despite its relative reduction in importance, the agricultural sector continues to play an essential role. Furthermore, because petroleum is a waste asset, the oil sector may not continue to dominate the economy in the future. This is especially true given that, due to a severe oil glut in February 1986, the price of oil per barrel plummeted from $\$ 28.00$ to $\$ 14.0$. (National Bureau of Statistics, 2018). Furthermore, if oil becomes scarcer in the future, the agriculture sector will continue to play a crucial role in the economy. It is consequently critical to revitalize agriculture by providing the necessary incentives and inputs, particularly financial resources, to convert it from its current status.

\section{Agriculture and Earnings from Exports}

Agriculture's importance can also be assessed in terms of its contribution to export revenues. Table $1 \mathrm{i}$ illustrates Nigeria's export revenues and the proportion of agriculture to export earnings from 1960 to 1995 . Agriculture raised its contribution in absolute terms from N282.4 million in 1960 to N13852.7 million in 1995. However, its relative share fell from 83.2 percent in 1960 to only 1.8 percent in 1995 . The poor productivity performance and relative importance of the petroleum sector are generally cited as factors for this trait. Apart from these factors, the relative decline of agriculture can be attributed to a drop in global demand for primary products, which account for the majority of Nigerian agricultural exports, as well as increased use of major proportions of some of these products as raw materials due to domestic industrial growth in Nigeria. To assure greater export revenues and an adequate supply of raw materials for the growth of local industries, a strategy for enhanced output is required. Agriculture's Terms of Trade declined from 1.76 in 1970-74 to 0.48 in 1975-79, 0.22 in 1980, 0.19 in 1985, and barely 0.55 in 1990 and 0.21 in 1992, before rising to 0.55 in 1990 and 0.21 in 1992. (Anyanwu and colleagues, 1997).

\section{Agriculture Capital Funding}

Between 1970 and 1995, there was a notable increase in federal capital investment on agriculture. Capital expenditure on agriculture increased from N5.6 million in 1970 to N2,414.2 million in 1995 in absolute (nominal) terms. The tiny share of agricultural expenditure in overall government expenditure, which climbed from 2.54 percent in 1970 to 11.53 percent (peak) in 1990 to only 1.99 percent in 1995, is one element that stands out. (Anyanwu, et al.) 
Impact Assessment of Agriculture and Manufacturing Sectors on economic Growth in Nigeria

Table 2: Federal Capital Expenditure on Agriculture 2001-2015

\begin{tabular}{llll}
\hline Year & $\begin{array}{l}\text { Agriculture's } \\
\text { Expenditure }\end{array}$ & $\begin{array}{c}\text { Capital } \\
\text { Total } \\
\text { Expenditure }\end{array}$ & $\begin{array}{l}\text { Federal } \\
\text { Agriculture's Expenditure as } \\
\text { Total }\end{array}$ \\
\hline 2001 & 5.6 & 220.9 & 2.54 \\
2002 & 211.2 & $3,518.2$ & 6.00 \\
2004 & 413.3 & $8,395.6$ & 4.92 \\
2005 & 305.8 & $5,464.7$ & 5.60 \\
2006 & 374.3 & $9,076.8$ & 4.12 \\
2007 & 442.7 & $6,372.5$ & 6.95 \\
2008 & 659.9 & $8,340.1$ & 7.91 \\
2009 & $1,733.2$ & $15,034.1$ & 11.53 \\
2010 & $1,598.2$ & $24,048.6$ & 6.65 \\
2011 & $1,219.0$ & $28,340.9$ & 4.30 \\
2012 & 941.3 & $39,763.3$ & 2.37 \\
2013 & $1,824.4$ & $97,079.4$ & 1.88 \\
2014 & $2,478.8$ & $120,492.9$ & 2.06 \\
2015 & $2,414.2$ & $121,138.3$ & 1.99
\end{tabular}

Sources: CBN, 2015

\section{Challenges of Agricultural Sector Financing in Nigeria}

Nigeria is still mostly an agrarian society. Approximately $70 \%$ of the population is involved in subsistence agriculture production. The downturn in agricultural production in Nigeria began in the early 1970s with the advent of the petroleum boom, and contradictions in government policy have made agriculture unattractive. Inadequate technology for farmers to use in order to produce in large quantities to meet local and international demand, natural disasters such as drought and pests destroying farm produce, poor transportation, weakened and non-existent infrastructure, and trade restrictions all contributed to a significant drop in agricultural output. Food production in Nigeria has been unable to keep up with the country's growing population, resulting in an increase in the amount of imported foods and the cost of importation. The government frequently imports significant amounts of machinery without a single service station to provide repairs and replacement parts. Apart from employing 51.3 percent of Nigeria's workforce and contributing for $70 \%$ of the non-oil sector's GDP (Bureau of Statistics, 2008). Nigeria still has vast swaths of productive agricultural land, as well as other resources that may be used to alter the economy. Despite these potentials, the sector is nonetheless characterized by low productivity. In the 1970s, for example, its contribution to GDP averaged 12 percent, resulting in growing import costs and a massive balance of payment imbalance. As a result, the country's ability to fulfill its traditional role of food provision, employment, and foreign exchange generation has been hampered by a slew of socioeconomic and financial issues, including a lack of funding, insufficient credit to local farmers and agro-business owners, and insecure macroeconomic policies. (National Bureau of Statistics, 2014).

Nigerian manufacturing and industrialization

It has been suggested that the fastest way for a country to achieve sustained economic growth and development is through technological innovation, enterprise development, and industrial capacity, rather than its endowed material resources or large people resources. For example, despite its limited natural resources and the challenges posed by persistent inflation in the 1920s, Germany has successfully exploited the manufacturing sector and risen to become Europe's and the world's fourth largest economy (Kayode, 1977).

The manufacturing sector is used to determine a country's economic efficiency in the modern world (Amakom, 2012). However, since the discovery of crude oil in Nigeria in the late 1950s, the country has shifted away from its preeminent developing industrial production base and placed a heavy emphasis on crude oil production (Englama, 2010); this has jeopardized the country's economic activities and exacerbated unemployment. Nigeria, as a giant of Africa, has long been regarded as a country endowed with vast human and material resources; however, the country's under-utilization of these resources has resulted in widespread poverty, a low standard of living at the individual level, and rising unemployment as a result of the country's continued mono-economic practice and severe neglect of other economic sectors such as agriculture, tourism, mining, and manufacturing. The industrial sector includes manufacturing as a subcategory (processing, quarrying, craft and mining). It entails turning raw materials into completed consumer items, as well as intermediate and producer commodities. 


\section{Impact Assessment of Agriculture and Manufacturing Sectors on economic Growth in Nigeria}

Manufacturing, like other industrial activity, produces jobs, helps to enhance agriculture, and diversifies the economy while also allowing the country to increase its foreign exchange reserves, allowing local workers to gain skills. It reduces the risk of overreliance on international commerce and encourages the most efficient use of available resources. The extent to which the other components of the industrial sector are efficiently exploited is measured by the degree of manufacturing (Kaldor, 1967)

\section{The Manufacturing Industry's Importance}

Manufacturing activities have a large impact on a country's economy. For example, in industrialized economies, they account for a significant share of total economic activities; in Nigeria, the subsector accounts for around 10\% of total GDP annually. Manufacturing activities employ roughly $12 \%$ of the entire workforce in the formal economy. Manufacturing encompasses a wide range of activities, from minor agro-based enterprises to large iron and steel companies. In a developed economy, the manufacturing sector is a leading sector in a different way: it is a way of increasing products related to import substitution and expansion, generating foreign exchange earnings and per capita income, and causing distinct consumption patterns (Anyanwu, 2000). However, manufacturing enterprises' efficacy is dependent on the availability of resources, such as raw materials and financial resources, to meet demand; this necessitates the financial sector in Nigeria investing a significant amount in expanding the subsector of the economy.

\section{The Nigerian manufacturing industry's structure}

Nigeria's manufacturing industry is one of the most dynamic in the world. Using the index of manufactured production, the manufacturing sector expanded from 1970 (when the civil war ended) and 1982. Manufacturing's average annual growth rate was faster in the second millennium of the 1970s than in the first, and it began to increase in the first half of the 1980 s, before declining after 1982. For the years 1982, 1984, 1985, and 1986, the manufacturing production index exhibited a negative growth rate of 28.6, 12.0, 64.3, and 21.8 percent, respectively (Anyanwu et al,1997). Manufacturers Association of Nigeria (Manufacturers Association of Nigeria, 2012). Nigeria's manufacturing industries have done well in the manufacture of goods for the country thus far. According to a recent survey, Nigerian commodities are exported to other countries. Nigerians are increasingly purchasing things created in the country. The industrial sector's performance improved slightly in the first half of 1997, with the industry's production index 132.6 increasing by 0.69 over the same period in 1996 , but declining by 0.2 percent in the second half of the same year. Mining and manufacturing production increased by 1.0 and 0.4 percent, respectively, to account for the increase in output compared to the same time in 1996. (National Bureau of Statistics, 2014).

Nigeria's Manufacturing Sector: Structural Changes and Growth Manufacturing accounted for 4.8 percent of Nigeria's GDP in 1960, growing to 6.9 percent in 1965 and 7.2 percent in 1970. In 1975, however, this figure had dropped to to 5.6 percent. In 1980, it was 8.3 percent, and in 1985, it was 8.6 percent. Its proportion grew to 8.51 percent in 1991, after which it fell steadily each year until it reached 6.88 percent in 1995, much below its 1965 and 1980 levels. High production costs due to the high cost of foreign exchange, poor demand, persistent power outages, insufficient raw materials supply, insufficient working capital, and frequent equipment malfunction have all been blamed for the poor manufacturing performance (NBS,2016).

\section{Strategies of Industrialization in Nigeria}

Nigeria and other West African countries have implemented a variety of industrialisation tactics as part of their development efforts. According to Anyanwu et al., 1997, the following industrialisation tactics were implemented in Nigeria:

(a) Import Substitution Strategy: Following independence, Nigeria switched from importing primary products from colonial masters to producing the items that were earlier imported. The fundamental goal was to reduce overdependence on foreign trade while also conserving foreign exchange. However, rather than manufacturing, it turned out to be a simple assemblage of those elements. Since practically every item required by the so-called industries was imported, the original claim was refuted.

(b)Strategy for Export Promotion:

Nigeria implemented an export promotion plan after recognizing the evident drawbacks of the import substitution method. This includes the creation and exportation of new products as well as those that were previously imported. The Nigerian Export Promotion Board (NEPB) was founded to encourage and implement this policy. This plan failed due to a lack of incentives and raw supplies. Since 1986, export promotion incentives have placed a renewed emphasis on this method.

c) A Strategy for Balanced Development

The unbalanced expansion of the industrial sector prompted the adoption of this policy. The basic goal of a balanced growth of all sectors is to foster increased inter-sectional and intra-industry links so that intra-industry transactions can grow.

(a) Resource-based local strategy:

Due to declining oil income and foreign cash for the importation of raw materials and spare components, the government opted to focus on an industrialisation plan based on local raw material sourcing. As a result, industries are urged to seek for local 


\section{Impact Assessment of Agriculture and Manufacturing Sectors on economic Growth in Nigeria}

substitutes or alternatives for their raw materials. Breweries, for example, are now growing and using local millet and maize, while the prohibition on wheat has prompted the creation of cornbread. This technique will aid in the most efficient use of local resources as well as the conservation of foreign exchange, among other benefits.

\section{Industrialization Incentives from the Government}

According to Anyanwu et al., in 1997, the governments of West African countries used a variety of incentives to stimulate industrialization and related tactics. These are some of them:

(a) Tax Holiday: For the first five years of operation, infant or new industries are exempt from paying profit tax. The goal is to shield them from worldwide competition and allow them to save enough money to expand.

(a) Tariff Protection: The government may levy high import tariffs on foreign goods in order to shield domestic industry from international competition.

(c) Import Duty Relief: The government may offer import duty relief to industries, especially new ones, for the importation of capital equipment in some situations.

(d) Total Ban on Some Imported Items: In Nigeria, the government has imposed a total ban on certain foreign goods in order to safeguard local industries producing similar goods and to stimulate increasing local production.

(e) Supportive Activities: The government provided further incentives in the form of grants, such as the construction of industrial estates.

(f) Loans: In Nigeria, there are criteria for credit allocation to the industrial sector by financial institutions such as commercial banks, merchant banks, and industrial development banks.

(g) Accelerated Depreciation Allowance: The government also provides another type of income tax relief by allowing businesses to set aside large sums to cover wear and tear on their machinery and equipment.

g) Direct Government Involvement:

The government has also begun to directly participate in certain vital industries, either on its own or in collaboration with foreigners or local entrepreneurs.

I Approved User Scheme: This entailed the application of reduced duty rates to a limited number of industrial imports of manufactured goods.

(j) Export Promotion Incentives: In Nigeria, export promotion incentives include a refund of import duty on raw materials used to make export goods, a refund of excise duty paid on export manufactured goods, a 30 percent exemption from the import levy on raw materials imported for export production (since 1986), a generous import license for importing raw materials for export production, and exporters keeping $25 \%$ of their foreign exchange earnings from export.

(k) The establishment of special industrial development financial institutions such as the Nigeria Industrial Development Bank (NIDB) and the Nigerian Bank for Commerce and Industry (NBCI).

\section{Empirical literature}

The evidence for a relationship between agricultural production and industrial development is contradictory. Because Nigeria is an import-dependent economy, particularly for capital goods, and because the rate of exchange of a country's currency to its trading partner's currency is so significant, a number of writers have voiced their interest and positions on this topic. The fluctuating and depreciating character of such a key economic variable, as well as its effect on other areas of the economy, has sparked a major surge in interest in this field over the years. According to more recent data provided by Ekanem (1997), manufacturing enterprises are functioning at less than $40 \%$ capacity and are reliant on imports. For numerous years, the manufacturing industry has focused on raw material imports. This appears to be due to multinational firms' overcrowding of th is vital sector of the Nigerian economy. As a result, high borrowing rates, growing inflation, naira depreciation, foreign shortages, and consumers' strong opposition to local items have all harmed this sector.

According to Olisadebe (1991), the naira exchange rate is one of the most actively discussed topics nowadays due to its macroeconomic influence, particularly in Nigeria.

Using an ordinary least squares technique, Chinweoke, Egwu, and Nwabeke (2015) studied the influence of commercial bank loans and advances to the agricultural and manufacturing sectors on economic growth in Nigeria from 1994 to 2013. Bank loans and advances to the agricultural and manufacturing sectors have a statistically significant impact on economic growth, according to the findings of the study.

From 1980 to 2011, Uzomba, Chukwu, Jumbo, and Nwankwo (2014) evaluated the impact and determinants of Deposit Money Banks' loans and advances to Nigeria's agricultural sector. The researchers used the Multiple Ordinary Least Square (OLS) Regression, Stationary Test, Co-integration Test, Parsimonious Error Correction Mechanism, and Granger Causality Test. The study found that deposit money bank loans and advances had a favorable impact on the agriculture industry. 


\section{Impact Assessment of Agriculture and Manufacturing Sectors on economic Growth in Nigeria}

Adeyinka, Daniel, and Olukotun (2015) looked at the role of commercial bank credits in financing Nigeria's agricultural sector, using secondary data from 2002 to 2014 on sectoral distribution of commercial bank loans and advances to the agricultural sector, commercial bank liquidity ratios, cash reserve ratios, and money market minimum rediscount rates. The data was analyzed using Multiple Regression of OLS to estimate the model, and it was discovered that the cash reserves ratio and rediscount rate are not statistically significant, while the liquidity ratio is statistically insignificant. The study recommended that banks provide a means of monitoring the end use of the loans given to farmers so that they can manage the loans effectively and efficiently.

Toby and Peterside (2014) looked at the role of banks in financing Nigeria's agriculture and manufacturing sectors from 1981 to 2010. The study looked at agricultural and manufacturing contributions to GDP, commercial bank lending to agriculture, merchant bank lending to agriculture, commercial bank lending to manufacturing, and merchant bank lending to manufacturing. The study used two levels of analysis, one using descriptive analysis directly on the panel data 1 and the other using multiple regression analysis on the panel data 2. They discovered that banks' role in assisting the agricultural and manufacturing sectors' contributions to economic growth is still restricted. As a result, it is recommended that monetary policy instruments emphasize mandatory sector credit allocation with proper incentives in order to increase the flow of funds from banks to the real sector.

The impact of commercial bank loans on manufacturing sectors was explored by Ogar, Nkamene, and Effiong (2014). Secondary data was employed in the study, including manufacturing production, commercial bank loans, and commercial bank interest rates. The models were used to determine the association between dependent and independent variables using ordinary least square of multiple regressions, and the results suggest that commercial bank credits have a substantial relationship with the manufacturing sector. It was suggested that the government work to ensure that there are enough and available credits for the industrial sector in Nigeria, all at a reasonable interest rate.

Sogules and Nkoro (2016) looked at how bank loans to the agriculture and manufacturing sectors affected economic growth. They analyzed annual time series data from 1970 to 2013 using co-integration and the Error Correction Mechanism (ERM). It was discovered that there is a long-term link between bank credit to the agricultural and manufacturing sectors and economic growth. According to the ERM findings, bank credits to the agricultural sector had a negligible negative impact on economic growth, whereas bank credits to the manufacturing sector had a considerable negative impact on economic growth in Nigeria. According to the report, bank lending to the agricultural and manufacturing sectors should be closely regulated to ensure that monies intended for these sectors are not diverted to other uses. To lessen the risks associated with lending to agriculture and manufacturing sector entrepreneurs, bank credits should be subjected to entrepreneurial development training.

\section{METHODOLOGY AND MATERIALS}

The primary data collection strategy employed in this study is secondary. Secondary data can be found in books, unpublished essays, journals, government reports, magazines, and the internet, among other places. The data for this study is made up of secondary time series spanning the years 1987 to 2019. The data comes from a variety of sources, including the Statistical Bulletin of the Central Bank of Nigeria and the National Bureau of Statistics.

\section{Model Specification}

The functional relationship between the variables is presented thus:

$M V A=f(R G D P, A G R Q, G O E X A$.$) .$

The functional relationship is translated into an econometric model for regression:

$M V A=\beta_{0}+\beta_{1} R G D P+\beta_{2} A G R Q+\beta_{3}$ GOEXA $+\mu$

Where

MVA= Manufacturing Value-added

RGDP $=$ Real Gross Domestic Product

$A G R Q=$ Output of the Agricultural Sector

GOEXA $=$ Government Expenditure on Agriculture

$\mu=$ The stochastic error term

$\beta_{0}, \beta_{1}, \beta_{2}$ and $\beta_{3}$ are parameters of the model.

\section{Estimation Techniques}

The Ordinary Least Square estimation technique, which was utilized to estimate the associations between the variables, was used as an analysis technique in this study. The Error Correction Mechanism ECM was also incorporated in the estimating model in order to better explain the dynamic nature of the relationship. This is particularly significant since it has the ability to reconcile short-term fluctuations with long-term equilibrium.. Thus, the proper model specification is stated below: 
Impact Assessment of Agriculture and Manufacturing Sectors on economic Growth in Nigeria

$$
\triangle M V A=\beta 0+\beta 1 \Delta R G D P+\beta 2 \Delta A G R Q+\beta 3 \Delta \text { GOVEXAM }+\alpha E C M
$$

Where $\beta 0$ is constant while $\alpha$ is seen as the error correction term which is expected to be negative and lies between the value of zero and one (0 and -1$)$.

IV. RESULTS AND DISCUSSION OF FINDINGS

Table 3: Results of Stationarity Tests

\begin{tabular}{lcccc}
\hline Variables & ADF & Test & Mackinnon & order of \\
Statistics & value (5\%) & Remark \\
\hline RGDP & -5.720837 & -2.967767 & $1(1)$ & Stationary \\
MVA & -7.429004 & -2.971853 & $1(1)$ & Stationary \\
AGRQ & -6.833201 & -2.981038 & $1(1)$ & Stationary \\
GOEXA & -7.289343 & -2.976263 & $1(1)$ & Stationary \\
\hline
\end{tabular}

Source: Author's Computation from E-view (2021)

The apriori expectation when using the ADF test is that a variable is stationary when the value of the ADF test statistics is greater than the critical value at $5 \%$. From the results, all the variables were found to be integrated of order one.

Table 4: Pairwise Granger Causality Tests

\begin{tabular}{|c|c|c|c|}
\hline Null Hypothesis: & Obs & F-Statistic & Prob. \\
\hline MVA does not Granger Cause RGDP & 28 & 0.18655 & 0.8311 \\
\hline RGDP does not Granger Cause MVA & & 0.11843 & 0.8889 \\
\hline AGRQ does not Granger Cause RGDP & 28 & 0.47386 & 0.6285 \\
\hline RGDP does not Granger Cause AGRQ & & 0.34720 & 0.7103 \\
\hline GOEXA does not Granger Cause RGDP & 28 & 1.10231 & 0.3490 \\
\hline RGDP does not Granger Cause GOEXA & & 0.82658 & 0.4501 \\
\hline AGRQ does not Granger Cause MVA & 28 & 5.01384 & 0.0156 \\
\hline MVA does not Granger Cause AGRQ & & 0.72278 & 0.4961 \\
\hline GOEXA does not Granger Cause MVA & 28 & 2.12027 & 0.1429 \\
\hline MVA does not Granger Cause GOEXA & & 4.15488 & 0.0288 \\
\hline GOEXA does not Granger Cause AGRQ & 28 & 0.64194 & 0.5354 \\
\hline AGRQ does not Granger Cause GOEXA & & 4.13054 & 0.0293 \\
\hline
\end{tabular}

Source: author's computation from E-views (2021)

The Granger causality shows that no causal relationship exists between Manufacturing Value Added and Real Gross Domestic Product at $5 \%$ level of significance. This is because the probability of the F-Statistics for the pair of null hypothesis was all greater than 0.05. So also, Agricultural output and Real Gross Domestic Product, Government Expenditure on Agriculture and Real Gross Domestic Product. But a uni-directional relationship exists between Manufacturing Value-added and Agricultural output. That is, the manufacturing value added is causing the agricultural output, but the agricultural output is not causing manufacturing value added at 5\% level of significance. MVA is also causing the GOEXA but GOEXA is not causing MVA. Same with AGRQ causing GOEXA but GOEXA is not causing AGRQ in the Nigerian Economy. That is the resulting alternate between no causality and a unidirectional relationship among the variables in question. 
Impact Assessment of Agriculture and Manufacturing Sectors on economic Growth in Nigeria

Table 5: Error correction result

Dependent Variable: MVA

Method: Least Squares

Date: 10/10/21 Time: 12:03

Sample (adjusted): 19872019

Included observations: 31 after adjustments

\begin{tabular}{lllll}
\hline \hline Variable & Coefficient & Std. Error & t-Statistic & Prob. \\
\hline \hline C & 140.0405 & 10.72964 & 13.05174 & 0.0000 \\
GOEXA & 0.753519 & 0.543251 & 1.387055 & 0.1782 \\
AGRQ & 0.047792 & 0.008527 & 5.604949 & 0.0000 \\
RGDP & 1.766535 & 1.967517 & 0.897850 & 0.3782 \\
ECM(-1) & 0.619202 & 0.240984 & 2.156080 & 0.0413 \\
\hline \hline R-squared & 0.874146 & Mean dependent var & 202.4586 \\
Adjusted R-squared & 0.839837 & S.D. dependent var & 83.41696 \\
S.E. of regression & 40.87969 & Akaike info criterion & 10.41473 \\
Sum squared resid & 40107.58 & Schwarz criterion & 10.65047 \\
Log-likelihood & -146.0136 & Hannan-Quinn criteria. & 10.48856 \\
F-statistic & 23.14684 & Durbin-Watson stat & 1.537049 \\
Prob(F-statistic) & 0.000000 & & \\
\hline \hline
\end{tabular}

Source: Author's computation using E-view (2021)

The absolute value of the ECM depicts how quick equilibrium is restored in the system in the event of temporary shock. The sizes of the ECM indicate the speed of adjustment of any disequilibrium toward a long-run equilibrium state since the deviation is corrected through a series of partial short-run dynamics. The coefficient of the ECM (-1) is (0.619202). The coefficient indicates that $62 \%$ of the disequilibrium in the system is offset by the short run adjustment annually to restore longrun equilibrium. This implies that the system corrects to equilibrium in the following year at the speed of $62 \%$.

Table 6: The result of the OLS is presented below

Dependent Variable: MVA

Method: Least Squares

Date: 10/10/21 Time: 11:59

Sample: 19872019

Included observations: 30

\begin{tabular}{lllll}
\hline \hline Variable & Coefficient & Std. Error & t-Statistic & Prob. \\
\hline \hline C & 132.3378 & 10.93505 & 12.20367 & 0.0000 \\
GOEXA & 0.873032 & 0.569553 & 1.690857 & 0.1028 \\
AGRQ & 0.045142 & 0.009023 & 5.002933 & 0.0000 \\
RGDP & 2.866311 & 1.782425 & 1.608096 & 0.1199 \\
\hline \hline R-squared & 0.817974 & Mean dependent var & 197.8433 \\
Adjusted R-squared & 0.791202 & S.D. dependent var & 85.77570 \\
S.E. of regression & 43.63602 & Akaike info criterion & 10.51321 \\
Sum squared resid & 49506.65 & Schwarz criterion & 10.70003 \\
Log-likelihood & -153.6981 & Hannan-Quinn criteria. & 10.57298 \\
F-statistic & 18.68544 & Durbin-Watson stat & 1.563694 \\
Prob(F-statistic) & 0.000000 & & \\
\hline \hline
\end{tabular}

Source: Author's computation from E-view (2021) 


\section{Impact Assessment of Agriculture and Manufacturing Sectors on economic Growth in Nigeria}

From the estimated results, the coefficient of the constant parameter (132.3378) is correctly signed and statistically significant with the probability of (0.0000). this indicates that if all the explanatory variables are held constant, the value of MVA will be 133.4478 units. The coefficient of GOEXA is (0.873032), which confirmed the apriori expectation of a positive sign. It is statistically insignificant at $5 \%$. This is because the probability is greater than 0.05 percent. That is $(0.1028>0.05)$. This implies that a unit increase in GOEXA will lead to a $96 \%$ increase in Manufacturing Value Added.

The coefficient of the agricultural output also confirmed to the apriori expectation. It has a positive sign, indicating a positive relationship between MVA and the Agricultural output. The coefficient of AGRQ is (0.045142), indicating that a unit change in AGRQ will lead to a change in Manufacturing Value Added by 5\%. The result is also statistically significant at 0.05 percent level with the probability of (0.0000). The coefficient of Real Gross Domestic Product is correctly signed (2.866311) and this met the apriori expectation of a positive sign and is statistically insignificant at $5 \%$ level of significance with the probability of 0.1199 .

The coefficient of determination R-Squared $\left(R^{2}\right)$ is 0.817974 which shows that about $82 \%$ of the variation in Manufacturing Value Added is as a result of changes in the explanatory variables (GOEXA, AGRQ and RGDP) while the remaining $23 \%$ is explained by the dummy variables. That is, there is a strong relationship between the manufacturing sector and the agricultural output in Nigeria. The Durbin Watson is 1.563694. This shows that there is no autocorrelation in the equation.

The F-Statistics with the value of 18.68544 and the Probability of 0.0000 indicated a strong linear relationship between the dependent and the independent variables.

\section{CONCLUSION AND RECOMMENDATIONS}

The study concluded that government spending on agriculture has a beneficial but minor impact on the industrial sector. As a result, the government should expand funding for the agricultural sector, which is Nigeria's main supply of raw materials for manufacturing.

The government must act quickly to develop the Nigerian agriculture industry by allocating more funds to the sector and ensuring that the funds are used wisely.

The government should also work to improve its incentives for the manufacturing sector in order to encourage higher industrial productivity and expansion. Tax Holiday: In other words, the government should exempt infant or new industries from paying profit tax for a period of time, say five years. The goal is to shield them from worldwide competition and allow them to save enough money to expand. Tariff Protection: To safeguard local industries from international competition, the government should set high import tariffs on foreign goods. Import Duty Relief: For the importation of capital equipment, the government should offer import duty relief to industries, particularly new ones. Total Import Restriction on Some Foreign Goods: The government should impose a total import ban on certain foreign goods in order to protect local industries that produce similar goods and to encourage increasing local production and consumption. The creation of special industrial development financial institutions, such as the Nigeria Industrial Development Bank (NIDB), will aid in the promotion and development of Nigeria's manufacturing industry.

\section{REFERENCES}

1) Adediran, O. \& Obasan, K (2010). The Role of the industrial sector in the economic development of Nigeria.Journal of Management and Society, 1 (2), 9-16.

2) Adeyinka A.J, Daniel,A.A\&Olutokun, G.A (2015). An assessment of the contribution of commercial banks to agricultural financing in Nigerian economy: International Journal of Advanced Academic Research-Social Science and Education,3 (2)

3) Adeyinka, .A.J., Daniel, A.A., \&Olukotun, G.A. (2015). An assessment of the contribution of commercial banks to agriculture financing in the Nigerian economy: International Journal of Advanced Academic Research-Social Science and Education 1(2), 35-37.

4) Amakom, U. (2012).Manufactured Exports in Sub-Saharan African Economies: Econometric Tests for the Learning by Exporting Hypothesis. American International Journal of Contemporary Research.Vol. (2) 4.

5) Anyanwu, C. (2000). Productivity in the Nigerian Manufacturing Industry.CBN Occasional Papers, Abuja CBN Research Department.

6) Anyanwu, J.C. Oaikhenan.H., Oyefusi.A. \&Dimowo.F.A. (1997). The Structure of the Nigerian Economy (1960-1997). Onitsha. Joadee Educational Publishers.

7) Central Bank of Nigeria (2010): Annual Report and Statement of Account.

8) Central Bank of Nigeria (2018). CBN Statistical Bulletin, 8 (2) 75. 
Impact Assessment of Agriculture and Manufacturing Sectors on economic Growth in Nigeria

9) Central Bank of Nigeria (CBN) Quarterly Statistical Bulletin, (2013)Central Bank of Nigeria Statistical Bulletin, various issues. Vol 20 Central Bank of Nigeria Annual Reports and Statements of Accounts, various issues.

10) Central Bank of Nigeria (CBN) Quarterly Statistical Bulletin, 2015,Vol 26, December.

11) Central Bank of Nigeria (Various Years). Annual Report and Statement of Account, Lagos.

12) Central Bank of Nigeria Statistical Bulletin, Various Issues.

13) Chinweoke, N., Egwu, C. C. \&Nwabeke, E. C. (2015). Impact of commercial Banks' Loans and advancesin agriculture and manufacturing Sectors on the Economic Growth of Nigeria $\quad(1994-2013)$.International Journal of Arts and Sciences, 08 (5), 29-36.

14) Chinweoke, N., Egwu, C. C. \&Nwabeke, E. C. (2015).Impact of commercial Banks' Loans and advances in agriculture and manufacturing Sectors on the Economic Growth of Nigeria (1994 - 2013).:International Journal of Arts and Sciences, 08 (05):. 29-36.

15) Ekanem (1997)."Corporate Strategy in the Manufacturing Sector. A Survey of Selected Companies in Nigeria" Unpublished Ph. D Thesis, River State University of Science and Technology, Port Harcourt.

16) Englama, A.; Duke, O.; Ogunleye, T. \& Isma'il, F. (2010) Oil Prices and Exchange Rate Volatility in Nigeria: An Empirical Investigation.Central Bank of Nigeria Economic and Financial Review. 48(3).

17) Kaldor, N. 1967.Strategic Factors in Economic Development. New York: W.F. Humphrey Press. Kayode, M.O. and O. Teriba, eds. 1977.Industrial Development in Nigeria.Ibadan: University Press.

18) Kayode, M.O. \& O. Teriba,E.D.S. (1977). Industrial Development in Nigeria. Ibadan: University Press.

19) National Bureau of Statistics (2014). Statistical Bulletin.

20) National Bureau of Statistics (2016).Statistical Bulletin.

21) National Bureau of Statistics (2018). Data and Analysis of Youth Unemployment in Nigeria.National Bureau of Statistics (NBS), Statistical Bulletin

22) Ogar A, Nkamere.S.E. \&Effiong C. “Commercial Bank Credit and its contributions to the Manufacturing Sector in Nigeria" Research Journal of Finance and Accounting:5(22)

23) Olisadebe E.U (1991). "Appraisal of Recent Exchange Rate Policy Measures in Nigeria",CBN Economic and Financial Review. 29 (2)

24) Sogules, I.W \&Nkoro E, (2016). BankCredits to Agricultural and Manufacturing sectors and Economic Growth in Nigeria, 1970 - 2013, International Journal of Economics and Financial Research, 2(4), 74-78

25) Toby,J.A \& Peterside, D.B (2014). Analysis of the role of Bank in financing the agricultural and manufacturing Sectors in Nigeria. International Journal Research in Business Management, 2(2), 9-22.

26) Uzomba, P. C., Chukwu, S. N., Jumbo, G. A. \&Nwankwo, N. U. (2014).An inquiring into the impact of deposit Money Banks' Loans and advances on agricultural Sector in Nigeria; 1980-2011.International Review of Social Sciences and Humanities, 7(2), 130-139. 